УДК 343.98

DOI https://doi.org/10.32837/apdp.v0i86.2449

М. А. Федорчук

\title{
ОСОБЛИВОСТІ ПРОВЕДЕННЯ ДОПИТУ ПІД ЧАС РОЗСЛІДУВАННЯ КРИМІНАЛЬНИХ ПРАВОПОРУШЕНЬ, ПОВ'ЯЗАНИХ ІЗ РЕЙДЕРСЬКИМ ЗАХОПЛЕННЯМ
}

Постановка проблеми. Розслідування кримінальних правопорушень, пов'язаних з рейдерським захопленням, потребує від слідчого творчого підходу і особливого вміння, враховуючи сучасні умови боротьби зі злочинністю. До їх числа належать: по-перше, зростання професіоналізму злочинців, посилення організаційних засад підготовки, вчинення та приховування кримінальних правопорушень; по-друге, небажання громадян брати участь у розслідуванні та непоодинокі випадки відмови в суді від раніше даних показань; по-третє, організаційні та інші недоліки системи розслідування (матеріально-технічне, науково-методичне забезпечення, кадри, рівень їх підготовки тощо) [1].

Під час збору доказової інформації в процесі розслідування кримінальних правопорушень, пов'язаних з рейдерським захопленням, головним етапом є допит. Із всього бюджету часу, виділеного слідчим на проведення слідчих (розшукових) дій, для проведення саме допиту використовується приблизно 85\%, а для проведення інших слідчих (розшукових) дій лише 15\% [1].

Допит є найбільш поширеним способом отримання доказової інформації. В той же час допит є однією з найбільш складних слідчих (розшукових) дій, i його проведення вимагає від слідчого високої професійної культури, глибокого знання психології людини і вірно вибраного тактичного підходу.

Обставини, які слідчий повинен з'ясувати під час проведення допиту, зазвичай пов'язані з подією злочину (спосіб, місце вчинення кримінального правопорушення, час, наслідки тощо) та встановлюють або спростовують винність у його вчиненні певних осіб та мотиви їх дій [2].

На думку В.Ю. Шепітька, інформація, що надходить від слідчого, може бути класифікована за функціональним призначенням на такі види:

- комунікабельно-забезпечувальна, тобто використовується для забезпечення успішного проведення допиту та встановлення психологічного контакту з особою, яка допитується;

- субстанціональна, яка спрямована на з'ясування основних відомостей по кримінальному провадженню, що виявляється у постановці питань, які визначаються предметом допиту;

- спонукаюча, яка використовується в тому разі, якщо особа, яка допитується, забула важливі для розслідування кримінального провадження обставини або відмовилися від їх викладання;

- викриваюча, яка покликана виявляти та викривати неправдиві дані в показаннях особи, яка допитується; 
- коригуюча, яка дозволяє уточнити показання або виявити та усунути викривлення, які є наслідком помилки свідка чи підозрюваного [2].

За характером вираження інформація поділяється на: а) змістовну (відомості, які повідомляються особі, яка допитується під час допиту); б) паралінгвістичну (жести, міміка, рухи тіла, звукові явища, які супроводжують мову людини); в) мімічна (лінгвістичні прояви, безпосередньо не пов'язані з мовою особи, яку допитують); г) конклюдентна (руки, жести, які вказують на що-небудь, з яких можна зробити висновок про наміри особи, її ставлення до чого-небудь); д) така, що відображає психофізіологічні реакції (почервоніння або збліднення шкіри обличчя, тремтіння рук, підвищена пітливість тощо).

Аналіз останніх досліджень і публікацій. Окремі проблемні питання організації і тактики проведення допиту висвітлювалися у спеціальній літературі вітчизняними вченими-криміналістами В.П. Бахіним, В.К. Весельським, А.Ф. Волобуєвим, Г.П. Власовою, В.О. Коноваловою, В.А. Журавлем, О.М. Процюк, Л.Д. Удаловою, С.С. Чернявським, Ю.М. Чорноус, В.Ю. Шепітьком, П.В. Цимбалом та іншими вченими.

Метою статті є дослідження особливостей проведення допиту під час розслідування кримінальних правопорушень, пов'язаних з рейдерським захопленням.

Виклад основного матеріалу дослідження. Допит як інформаційний процес має свою складну й багатоелементну структуру. Для досягнення цілей допиту необхідно правильно обрати тактику його проведення, що зводиться до використання певних тактичних прийомів, які сприяють одержанню більш докладної і повної інформації.

Вибір тактики допиту залежить від таких чинників: а) ситуації допиту; б) процесуального статусу допитуваного і рівня його зацікавленості в результатах розслідування; в) особливостей допитуваної особи (вік, характер, рівень правової поінформованості, наявність злочинного досвіду тощо); г) характер інформації та доказів, які є у слідства тощо [3].

Як свідчить аналіз слідчої практики, психологи із знанням невербальної комунікації доволі рідко залучаються до допитів підозрюваних, оскільки їх висновки мають лише допоміжний, рекомендаційний характер.

Слід пам'ятати, що успішний допит підозрюваного напряму залежить від того, наскільки слідчий підготовлений до нього. Йдеться про підготовку до допиту осіб, які вчинили кримінальне правопорушення, пов'язане з рейдерським захопленням особи підозрюваного, з'ясування умов, у яких вона живе і працює; визначення моменту і часу проведення цієї слідчої дії, з'ясування кола осіб, яких потрібно залучити до участі в допиті, розробку плану його проведення, визначення формулювань основних і контрольних запитань, а також усунення причин, які заважають підозрюваному давати правдиві показання. Непотрібно виключати випадки, коли в допиті може брати участь захисник.

Ситуація на допиті підозрюваного, що проводиться за участю захисника, повинна розглядатися із урахуванням конфліктності не лише із підозрюваним, а й його захисником, його ставленням, реакцією на цю конфліктність. Важливу роль тут відіграє психологічний компонент - наявність чи відсутність психологічного 
контакту слідчого як із підозрюваним, так із захисником. Якщо між слідчим і підозрюваним виникає конфлікт, то він виявляється і між слідчим та захисником і може мати як прихований, так і відкритий характер, тому що захисник пов'язаний зі своїм підзахисним процесуальними обов'язками [4].

Перед допитом важливо завчасно підготувати конкретні питання, які доцільно поставити. У них не повинно бути ніяких фактичних даних, які могли б підказати підозрюваному або навести його на думку про показання інших осіб [5].

Під час допиту підозрюваного недоцільно ставити навідні запитання. Особлива небезпечність навідних запитань полягає в тому, що окремим категоріям осіб притаманна підвищена вразливість, нерозвиненість логічного мислення, у результаті навіювання вони можуть вдаватись до самообмови, визнати себе винними у кримінальному правопорушенні, якого не вчиняли. Вільну розповідь підозрюваного, яка нерідко буває фрагментарною і недостатньо конкретною, треба вислухати, не перебиваючи і не ставлячи ніяких запитань [6].

У криміналістичних джерелах виділяють чотири основні ситуації допиту: 1) надання правдивих показань; 2) добросовісна помилка; 3) надання неправдивих показань; 4) відмова від надання показань [7].

У першому випадку допит відбувається в безконфліктній ситуації і починається з установлення з підозрюваним психологічного контакту.

Якщо підозрюваний зізнається у вчиненні кримінального правопорушення і готовий з подробицями розповісти про це, то потрібно запропонувати йому розповісти все в довільній формі, при цьому постійно слід аналізувати його показання і необхідно допитати по кожній з названих обставин. Тут потрібно з'ясувати всі деталі вчиненого кримінального правопорушення: за яких обставин у нього виник умисел на його вчинення; вчинив він кримінальне правопорушення один чи із співучасниками; чи не здійснював кримінальне правопорушення раніше; хто може підтвердити повідомлену ним інформацію. Допитуючи про спосіб вчинення кримінального правопорушення, шляхи підходу і відходу, важливо з'ясувати усі подробиці, звертаючи особливу увагу на обставини, які могли бути відомі тільки тому, хто вчинив кримінальне правопорушення і нікому більше, що саме змусило давати правдиві показання.

У другій ситуації є два основні варіанти: 1) підозрюваний не пам'ятає того, що цікавить слідчого; 2) повідомлене ним викликає сумніви внаслідок логічного чи фактичного протиріччя або невідповідності інформації, яка вже є у кримінальному провадженні [6].

У першому випадку доцільно застосувати тактичний прийом «нагадування», тобто ставити запитання, що допомагатимуть допитуваному згадати певні події, забуті ним, заповнити прогалини в показаннях. Тактичний прийом «наочність» з використанням різних наочних предметів (доказів тощо) допомагає відновити в пам'яті події, які відбулися.

У другому випадку варто розібратися в причинах, якими може бути пояснено невідповідність показань: наявність об'єктивних (умови сприйняття) або суб'єктивних (стан організму і ставлення до події) чинників, що вплинули на це [8]. 
Пропонуючи підозрюваному пояснити ті чи інші суперечності у його показаннях, викриваючи його у брехні, демонструючи безглуздість наведених ним доказів, доцільно поволі, поступово підводити його до думки про необхідність правдиво розповідати про вчинене кримінальне правопорушення [9]

Скерувавши розмову в русло так званих нейтральних інтересів, слідчий знімає тривогу і неспокій, створюючи доброзичливу атмосферу у відносинах. Так можна і навіть потрібно створювати «незаповненість». Цей прийом застосовується, коли слідчий має дані та докази, що проливають світло на окремі епізоди вчиненого кримінального правопорушення, проте ще не зрозуміла повна його картина [10].

У третій ситуації допиту необхідно виявити причини, які змушують підозрюваного давати неправдиві показання. Серед них можуть бути страх перед покаранням, сором перед своїми близькими, страх помсти від співучасників, небажання відшкодування матеріальної та моральної шкоди тощо.

Допитуваний, вважаючи, що може спростувати ці факти так само, як і попередні, намагається впоратися з новими логічними судженнями слідчого, проте це для допитуваного видається неможливим, і у нього виникає стан фрустрації. Не будучи здатним подолати розгубленість, підозрюваний повідомляє те, що мало місце насправді [10].

У четвертій ситуації допиту, коли підозрюваний взагалі відмовляється від дачі показань, також необхідно з'ясувати причини такої позиції. У такій ситуації можуть застосовуватись такі тактичні прийоми: роз'яснення і переконання, спрямовані на подолання позиції відмови від надання показань; проведення розмови на абстрактну тему; втягування допитуваного у спір; демонстрація намірів і можливостей слідства щодо збирання, дослідження і використання доказової бази; психологічний вплив на позитивні якості допитуваного, щоб спонукати його до каяття; порядок пред’явлення доказів; відтворення слідчим обставин вчинення кримінального правопорушення; роз'яснення підозрюваному справжньої суті почуття дружби і товариства, які не мають нічого спільного з круговою порукою.

Важливе значення під час доказування кримінального правопорушення, пов’язаного з рейдерським захопленням, має інформація, добута під час допиту свідків і підозрюваних.

Висновки. У процесі допиту свідків у кримінальних провадженнях, пов'язаних з рейдерськими захопленнями, необхідно з'ясувати: індивідуальні можливості людини до сприйняття та запам'ятовування; що насамперед привернуло увагу свідка; хто ще міг бачити подію; яке було освітлення; який час доби; чи чули ще якісь звуки в даний час; встановлюються дані про підозрюваного, його особливі прикмети, особливості одягу, мови, характер його дій; про напрямок, у якому він зник; транспортні засоби, викрадені предмети та їх індивідуальні особливості.

Допитуючи осіб, які затримали злочинця на місці події, слід встановити, за яких обставин вони його помітили, що навело їх на думку про вчинення кримінального правопорушення, пов’язаного з рейдерським захопленням, які дії вжиті для затримання, як поводився затриманий, наявність можливих співучасників.

Під час розслідування кримінальних правопорушень, пов'язаних з рейдерськими захопленнями, важливим є допит потерпілих, що також має свої особливості. 
По-перше, на відміну від показань свідка, надання показань потерпілим є лише його правом для захисту своїх законних інтересів. По-друге, показання потерпілого завжди мають значення для розслідування кримінального правопорушення, це пов'язано з тим, що їх відсутність у матеріалах провадження є порушенням вимог закону про повноту, всебічність та об’єктивність дослідження. По-третє, процесуальний статус потерпілого виявляється в його зацікавленості у розслідуванні кримінального правопорушення. По-четверте, показання потерпілого мають особливу процесуальну природу, оскільки йому заподіяно злочином матеріальну, моральну шкоду чи тілесні ушкодження, тому його показання теж можуть бути як джерелом доказів, так і засобом захисту своїх інтересів через те, що законодавець дозволяє йому посилатися на інші докази, заяви, клопотання тощо.

За КПК України можливості слідчого, прокурора у розслідуванні кримінальних правопорушень, пов'язаних з рейдерським захопленням, значно розширено. Це стосується можливості проведення зазначеними особами допиту осіб, перелік яких зазначений у кримінальному процесуальному законодавстві, у режимі відеоконференції.

\section{Jimepamypa}

1. Бахін В.П., Весельський В.К. Тактика допиту : навч. посібник. Київ, 1997. 64 с.

2. Шепітько В.Ю. Допит: науково-практичний посібник. Харків, 1998. 35 с.

3. Бахін В.П. Криміналістика Ч.1: курс лекцій. Ірпінь : Академія ДПС України, 2002. 356 с.

4. Зайцева И.А. Тактика допроса подозреваемого и обвиняемого, проводимого при участии за щитника : дисс. ... канд. юрид. наук : 12.00.09. Саратов. 2002. $244 \mathrm{c.}$

5. Корольчук М.С., Крайнюк В.М., Марченко В.М. Психологія: схеми, опорні конспекти, методики : навч. посіб. для студ. вищ. навч. закл. Київ, 2010. 320 с.

6. Кайгородова О.С. Расследование грабежей и разбоев, совершенных несовершеннолетними : дис. ... канд. юрид. наук : 12.00.09. Тюмень. 2006. 238 с.

7. Весельський В.К. Сучасні проблеми допиту (процесуальні, організаційні і тактичні аспекти) : монографія. Харків. 1999. 126 с.

8. Вапнярчук В.В. Досудове провадження. Глава 14. Кримінальний процес: підручник. Харків : Право. 2013. С. 334.

9. Соловьев А.Б., Центров Е.Е. Допрос на предварительном следствии: метод. пособ. 2-ге изд., перераб. Москва, 1986. $114 \mathrm{c.}$

10. Дубинский А.Я. Исполнение процессуальных решений следователя: правовые и организационные проблемы. Киев, 1984.182 с.

\section{Анотація}

Федорчук M. A. Особливості проведення допиту під час розслідування кримінальних правопорушень, пов'язаних із рейдерським захопленням. - Стаття.

У статті піднімається питання використання засобів невербальної комунікації до підозрюваних осіб, які дають можливість слідчому у тій чи іншій невербально-комунікативній слідчій ситуації під час допиту підозрюваної особи оперативно обрати найбільш розумний, правильний напрям його процесуальної і тактичної діяльності. Також невербально-комунікативна ситуація в широкому їі розумінні дає змогу слідчому оперативно вирішувати тактико-діагностичні і частково процесуально-діалектичні завдання.

Охарактеризовано таку першочергову слідчу розшукову дію, як допит, яка під собою розуміє інформаційний процес та має свою складну й багатоелементну структуру. Для досягнення цілей допиту необхідно правильно обрати тактику його проведення, що зводиться до використання певних тактичних прийомів, які сприяють одержанню більш докладної і повної інформації.

Автором проаналізовано, що у низці випадків неправдиві показання можуть бути пов'язані з обмовлянням або самообмовою. За підозри на обмовляння необхідно обов'язково виявити характер 
взаємостосунків, розбіжності інтересів. Так, якщо допитуваний викривається у брехні іншою особою, яка також є учасником провадження, то перш ніж використовувати ці показання, слід з'ясувати їхні стосунки: як вони познайомились, чи не було між ними неприязні, сварок, чи немає підстав для обмовляння. Якщо є, то слід поміркувати про доцільність пред’явлення цих показань, якщо ж скаже, що стосунки нормальні, то є менш імовірною заява про обмовляння.

Аргументовано, що поширеним випадком неправди з боку підозрюваного є повідомлення про своє алібі. Після того як допитуваний заявив про своє алібі, слідчий повинен конкретизувати його просторово-часові характеристики. 3 цією метою на стадії постановки запитань під час проведення допиту слідчому доцільно запропонувати підозрюваному самостійно записати до протоколу показання про алібі, скласти схему свого маршруту із зазначенням певних місць та часу, коли він там перебував. Під час допиту застосовується такий тактичний прийом, як деталізація показань. Підозрюваний, який заявив заздалегідь непідготовлене неправдиве алібі, зазвичай не має часу та можливості детально продумувати свої показання щодо узгодженості в деталях.

Ключові слова: допит, тактичні прийоми, показання, невербальна комунікація, допитувані особи, досудове розслідування.

\section{Summary}

Fedorchyk $M$. A. Features of interrogation in the investigation of criminal offenses related to the raid. - Article.

The article raises the issue of using non-verbal means of communication to suspects, which allow the investigator in a non-verbal-communicative investigative situation during the interrogation of the suspect to quickly choose the most reasonable, correct direction of his procedural and tactical activities. Also, the non-verbal-communicative situation in its broadest sense allows the investigator to promptly solve tacticaldiagnostic and partially procedural-dialectical tasks.

The primary investigative search action is characterized as an interrogation, which means the information process and has its own complex and multi-element structure. To achieve the goals of the interrogation, it is necessary to correctly choose the tactics of its conduct, which is reduced to the use of certain tactics that contribute to obtaining more detailed and complete information.

The author analyzes that in some cases, false testimony may be related to defamation or selfincrimination. Suspicion of slander is necessary to identify the nature of the relationship, differences of interest. Thus, if the interrogated person is exposed in a lie by another person who is also a participant in the proceedings, then before using these testimonies, it is necessary to find out their relationship: how they met, whether there was hostility between them, quarrels, whether there are grounds for objections. If so, consideration should be given to the appropriateness of presenting these testimonies, but if he says that the relationship is normal, then a statement of objection is less likely

It is argued that a common case of untruth on the part of the suspect is a report of his alibi. After the interrogated has stated his alibi, the investigator must specify its spatio-temporal characteristics. To this end, at the stage of asking questions during the interrogation, the investigator should ask the suspect to write down the testimony of the alibi in the protocol, to make a diagram of his route indicating certain places and times when he was there. During the interrogation, such tactics as detailing the testimony are used. A suspect who has made an unprepared false alibi in advance usually does not have the time or ability to think through his or her testimony in detail.

Key words: interrogation, tactics, testimony, non-verbal communication, interrogated persons, pre-trial investigation. 